\title{
A REPORT ON THE RELIEF ORGANISATION IN HASTINGS ARISING OUT OF THE [MAGNITUDE 7.8] EARTHQUAKE IN HAWKE'S BAY [NEW ZEALAND] ON FEBRUARY 3, 1931
}

\author{
Edwin F. Scott ${ }^{1}$
}

\begin{abstract}
SUMMARY AND PREFACE by D. J. Dowrick ${ }^{2,3}$
At the time of the 1931 Hawke's Bay earthquake, 33 years old Edwin (Ted) Scott was employed as a civil engineer by the Christchurch Drainage Board. He was also a member of the Christchurch metropolitan emergency committee. In those two capacities he was sent to observe and report on the restoration of services in Hastings, where his father happened to be the municipal Electrical Engineer. He completed this report back in Christchurch, dated 24 April 1931. He later became Chief Engineer of the Christchurch Drainage Board.
\end{abstract}

The report is very well written giving detailed information on the immediate emergency response period in one of the worst affected towns, Hastings, where the intensity was Modified Mercalli X. This report is complementary to the overview paper on damage and intensities in the Hawke's Bay earthquake by Dowrick [1]. Scott's report contains much that is of value in planning response to future Civil Defence emergencies in New Zealand and elsewhere.

The report discusses the scale of the emergency in Hastings, the setting up of committees, dealing with the dead and injured, the roles of the Police, essential services (including lifelines), food supplies, and the work of the Citizens' Committee which steered and co-ordinated all of the emergency work on behalf of the community.

Apart from omitting the detail of some forms and certificates developed in the emergency. Scott's report is reproduced here in full. The few editorial additions and amendments, made for clarity, are given in square brackets.

\subsection{INTRODUCTION}

\subsection{Introductory}

This earthquake was a particularly severe one, with its centre just to the north of Napier. Napier and Hastings were the two boroughs most severely affected, but damage was reported from Gisborne to Dannevirke.

But as this report deals with Relief Organisation, it may be permitted if I confine my remarks to the one centre where this was most complete, and whence the greatest lesson may be derived.

\footnotetext{
${ }^{1}$ Civil Engineer, Christchurch Drainage Board in 1931

${ }^{2}$ Institute of Geological \& Nuclear Sciences, Lower Hutt

${ }^{3}$ Fellow
}

With this apology, therefore, I propose to speak of Hastings, which is an inland town of twelve thousand inhabitants, business centre of a large farming and fruit growing district.

Business is proceeding as usual when a calamity occurs that effectively stops the whole activity of the people, wrecks 200 of the business premises; kills over a hundred citizens; injures so many more that 2,500 immediately require surgical and medical attention; damages houses and their contents so effectually that the populace has to live out of doors; upsets power, light, sewerage and water supply; cuts off all communication with outside except by road; and, might I ask, what would you do? 
There are only a hand full of police, whose immediate care is for the dead; no navy; no regular military; and no prepared organisation.

Think what a catastrophe it is, and how much is to be done; of the dead and injured; of the desolation and wreckage; of the loss of food supplies and public services; of the hundred and one things that make up our civilised life, wrecked at one blow; and you will realise what faced the citizens of Hastings that day.

It is how they faced this situation and how they worked to get the wheels of business started again, that will be the main theme of this report.

\subsection{The 'Quake}

The earthquake of [Tuesday] February $3^{\text {rd }}, 1931$, occurred at ten minutes to eleven in the morning, with the men and girls at their businesses, the women at home or doing their morning shopping, the children at school. No pre-motion, no warning, a nerve shattering catastrophe that seemed to bring the world tumbling about their heads. Those of us who were not there cannot realise the awfulness of it all; to many it seemed the end of the world.

Naturally men's thoughts turned to their wives and families, and whoever could make their way to home or school to make sure that their loved ones were safe and sound. Then back to town to assist in rescuing the wounded and injured, retrieving the dead, and helping wherever possible. The air was full of cries, motor car horns beneath the debris were blaring out, fires started in several places, and the earth was still shaking. Amid the ruins and wreckage and in the dense pall of dust and smoke, men moved, some to retrieve papers and documents of their businesses left in their first rush, to try and secure strong room doors, others helping in the work of mercy; the firemen getting their engines and hose from the damaged station and quelling the fires, while the men of the power house staff re-entered the shaking building, started up the standby Diesel engines, and had the water supply pumps going within an hour and a half of the first shake. Every man to his job, and those without jobs, helping where and as best they could.

\subsection{Setting up Committees}

The Mayor of the town was unfortunately away at Waikaremoana, the Deputy Mayor was busy as he was Superintendent of the Fire Brigade, but managed to get word to the Town Clerk to arrange for a meeting of leading citizens in an open space in front of the wooden Bank of New South Wales building for 2 o'clock that afternoon.

An ex-Mayor of the borough was asked to address the assembled citizens. The full extent of the calamity was barely realised, but that it was extensive and serious could not be doubted, and strong and urgent measures were needed.

First and foremost, all military men were asked to meet in half-an-hour at a certain spot, elect a head of committee, and to promptly clear, picket, and then police the damaged area.
All carpenters and builders were asked to meet at another spot, elect a committee, and organise the systematic recovery of the injured and dead, and under direction of the Borough Engineer, pull over all dangerous walls.

Lawyer, bankers, business men, and other leading citizens were then asked to elect a Hastings Borough Earthquake Executive Committee. This Committee was the key of the whole situation, and was responsible for the splendid results obtained. It co-ordinated the whole of the work, and assumed the responsibility for all actions taken.

One of this Committee's first actions was the appointment of a Food Controller, who immediately took charge of this side of the situation, engaged his own staff, and arranged for supply and distribution.

I will now endeavour to traverse the main fields of work covered by the various committees. My information is not complete, but I hope it will serve as a basis for further investigation, and give a helpful outline of the whole situation.

\subsection{THE DEAD AND INJURED}

\subsection{Mortuary Depot}

A Mortuary Hospital and Receiving Depot for the dead was established at the YMCA within an hour of the "quake and had a Nursing Sister in charge, who, by the next morning, has gathered together a full staff. A Doctor was made available in case of any difficulty or doubt. By the end of the day nearly 50 bodies had been cared for. These were received from the police, and placed on clean sacks in rows in the gymnasium. They were then checked by the Records Officer, also the police, and numbered by the Sister, the police checking the numbers also. The number was attached to each coffin which the graveside officials checked.

Relations and friends only were allowed to view the bodies for the purposes of identification. Some bodies were beyond identification, and a few through certain injuries were unable to be placed inside, so were laid out under the trees, and received exactly the same treatment as those inside.

Most careful records were kept of all unidentified bodies, including measurements down to size of foot, and samples of clothing and all trinkets etc., were carefully put aside against the number of the corpse. Missing limbs were checked against every detached member found and in this way confusion was greatly eliminated. The bones of carcasses recovered from the ruins of butchers' shops, and dressed wax models from drapery establishments, were among the relics brought in for investigation. The undertakers worked night and day during the earlier days, and like the police, showed courtesy and gentleness in handling the dead. Records were regularly submitted to the YMCA Information Bureau.

\subsection{Burial}

The Borough Council held an emergency meeting on the evening of the "quake on the street in front of the Municipal Offices, and gave the Borough Engineer authority to employ 40 men to dig the graves for the following afternoon, and at 
another meeting next day instructed the Assistant Town Clerk to issue authority for the effecting of burials.

The Church of England clergyman had been a Chaplain to the Forces overseas, and arranged with his brother clergymen of other denominations to carry out the burial services on military lines. Twenty-five bodies were buried in a common grave the second day, but thereafter each was placed in a separate and numbered grave, with a small wooden cross giving such details as were known. Where no religious denomination was known, the surname was assumed to indicate nationality and the appropriate padre officiated.

Full records of all graves were kept by the clergy, so that relatives could later visit the graves.

\subsection{Care of the injured}

Royston Private Hospital was badly damaged, as was also the brick Memorial Maternity Hospital, so the Doctors decided to open an emergency Hospital in the Tea Kiosk at the Racecourse, which had been used as a hospital at Epidemic time.

The Doctors perfected their own staffing arrangements and were assisted by a member of the Executive Committee to take charge of the records staff and stores.

The injured as they arrived at the Hospital were examined by a Doctor, and the Accompanying Nursing Sister ticketed each one under the Doctor's directions. A Minister of religion also attended, and if [the] patient was conscious, took down details of name, etc., as well as enquiring of those bringing them in. Copies of these lists were sent to the YMCA Information Bureau.

Serious surgical cases were marked "theatre", others marked "ward" or "outpatient".

Nurses followed up and took charge, being guided by the directions on the tickets.

Those given morphia had a tab of sticking plaster placed on the forehead with the dose and the time marked on it.

As each patient was treated, his ticket was initialled by the Doctor as having had attention, to prevent wastage of time and duplication.

Luckily there was plenty of anaesthetics for a start. Dentists brought their gas apparatus and cylinders along for minor surgical cases, such as dressings and stitchings. Chemists immediately starts salvaging such drugs as were required from the wreckage of their shops.

Two dentists had portable X-ray plants undamaged, which were taken to the emergency hospital and used extensively.

There was a shortage of medical stores and certain drugs, and at one stage they were reduced to 4 gauze pads, but the local women got busy with their needles and made them up for the doctors. Aeroplanes and the Red Cross cars from outside centres greatly relieved the situation by bringing up stores. The Public Hospital stocks are usually inadequate for such an emergency as this. 2,500 patients were treated the first day.
A dental clinic was started by the next day; (but an old man was told to go to Palmerston North for the set of false teeth he wanted to chew the hard food which was offering in those first few days).

A lawyer was attached to the Hospital for making wills and receiving instructions from patients if required.

Boy Scouts promptly got into their uniforms (the uniform is a big thing) and were attached to the Hospital and to all committees, and did good service as messengers and orderlies.

Lost children were taken to the hospital till enquiries were made. There was also a Welfare Officer appointed.

Accommodation was very limited, and many normal cot cases had to be treated as outpatients. The Doctors prepared lists of outpatients, with times at which their wounds had to be dressed. The Hospital Transport Department organised cars and ambulances and brought in the patients at the time stated, and then returned them to where they were bivouaced.

The District Nursing Service on the second day started a house-to-house canvas, working block by block, to see if there were any injured, sick, or helpless people not receiving attention.

Plenty of medical assistance soon arrived, and by the fourth day, that is, the $7^{\text {th }}$ February, some of the volunteers had to be released to go back to their homes. The Racecourse Hospital was now a public hospital, under the control of the Hospital Board.

As from the $7^{\text {th }}$ also, two nurses had recommenced duties as District Nurses for urgent cases, and a Doctor was also released for urgent cases in town.

\subsection{POLICE}

\subsection{Pickets}

The first step of the hastily formed Citizens Committee was to arrange for the policing of the damaged area. The ordinary police force was fully occupied in taking charge of the dead as they were recovered from the wreckage, conveying them to the Mortuary Depot, and attending to identification and attendant records, and could not be of any assistance.

No one was normal, many, especially women, had an attack of excitement hysteria, and careered round in motor cars, charging in over debris to view all the damage, and greatly hampered all organised effort. Valuable contents of shops, warehouses, and business lay open to the light-fingered and the pilferer, and required protection.

The civilians who had had military experience were ordered to take over, and formed a committee; with a major in charge. A force of 150 special police was organised, working 2 shifts of 6 hours on and 6 hours off duty.

By 4 o'clock on the afternoon of the $3^{\text {rd }}$ the town was cleared of all unauthorised persons, and no one on any account was allowed to be in the damaged area after 8 p.m. 
The pickets took up positions in groups of three at a time, with two watches a day at each point. They were supplied with pick and axe handles as batons and wore armlets and belts. The need for some sort of uniform was badly felt, as there were several attempts at impersonation.

However, certificates were given to every man, which had to be shown on demand, while patrols under an officer went round visiting the Railway Station, Relief Depots, and seeing that all pickets were on duty and were relieved to time. Patrols also watched out for any pilfering, but were hampered at night by lack of torches. Adequate supplies did not arrive till Saturday $\left[7^{\text {th }}\right]$.

The Power House was running and the main Heretaunga Street was wired up for street lighting before dark, but the second big shake at $9 \mathrm{pm}$ the first Tuesday evening damaged the Power House, and the engines were out of commission till next afternoon. However, it was bright moonlight, being full moon that Tuesday, and street lighting was not urgently necessary. The electrical engineer had every street light in the town on by Sunday, though, and it inspired confidence at well as helping to prevent pilfering from private houses. The disaster naturally attracted hoboes and ne'er-do-wells from all parts of the country.

\subsection{Passage through damaged area}

One duty of the pickets was to prevent unauthorised passage through the damaged area. Every workman and official was therefore given a [dated certificate authorising access to all parts of broken area at all hours, signed by a Citizen Staff member and countersigned by the workman.]

As the production of passes was a slow process, armlets were prepared, and issued to officials and foremen. Workmen were taken through by their foreman. Also posters were pasted to the windshields of all official cars, and a list was supplied to every picket. Thus they could tell at a glance those entitled to pass, but if in any doubt they demanded the production of the official certificate.

The posters and armlets were as follows:

$\begin{array}{ll}\text { H.Q. } & \text { - Headquarters Citizens' Committee } \\ \text { Health } & \text { - House to House inspectors } \\ \text { Sanitary } & \text { - Disinfecting and Repair gangs } \\ \text { Traffic } & \text { - Municipal employees and other workmen } \\ \text { Relief } & \text { - Evacuation and other transport } \\ \text { The Red Cross } & \text { - Hospital and Medical }\end{array}$

\subsection{Picket at Mortuary depot}

A special picket was on duty here, and permitted no one to go near without a special permit. Especially in the later days the depot was in very strict isolation, and the special police on duty were instructed to knock anyone on the head if they attempted to pass without producing proper authority.

\subsection{Outlying Pickets}

On February $6^{\text {th }}$, the Citizen's Committee authorised the provision of pickets at Havelock North, Paki Paki, Fernhill, Maraekakaho, etc., to prevent as far possible persons coming into the Borough, other than those on official business. Pickets were also instructed to stop empty cars from leaving if they could take passengers. Many parents were anxious to get their children away, and empty cars willing to take passengers were referred to the Welfare Officer.

Patrols were also sent out to control traffic at damaged bridges.

\subsection{Handing over to Civil Police}

The major in charge of special police reported on February $7^{\text {th }}$ that his men were becoming exhausted with continuous work, and asked for between 40 to 60 Police Constables, or else some of the permanent artillery and other military staff. The Commissioner of Police met the Committee on Sunday morning, and announced that he had recruited 40 volunteers for duty outside the devastated area, where only 2 per cent of the houses were occupied.

On Monday the Citizen's Committee reported that as a result of a conference, the Commissioner had arranged for making 38 constables. The picketing was carried on until Wednesday, when the citizen police held a final parade and were given free rations for a week.

\subsection{Hotels}

All hotels not destroyed were closed in the Borough, and remained closed until after the control of the area was handed over to the Police Inspector on Wednesday, February $11^{\text {th }}$. The Inspector was authorised to use his discretion as to whether the bars might then be allowed to be publicly opened after Monday $16^{\text {th }}$ February.

I say publicly opened, because they were only "officially" closed. It was considered necessary to permit the consumption of a certain amount of fermented and spirituous liquor, and the bars were open for anyone to enter by the back way. But the nominal closing of the hotel gave the hotelkeeper a better control over his patrons, and a too free indulgence was more easily checked by refusing permission to enter the building.

\subsection{ESSENTIAL SERVICES}

\subsection{Power House}

Luckily the Power House building escaped the first 'quake, though the heavy foundation for the Diesel engines sounded as if they had been loosened - the engines when running sounding a little noisy.

Normally power is taken through the Hawke's Bay Power Board from the Government Hydro-Electric High Tension mains. But neither the Government nor the Power Board Transformers had been anchored, and toppled over with the earthquake, and power from that source was not received for several weeks.

The Engineers on duty at the time were permitted to rush home to see if their families were safe, and then hurried back to go over the plant, and get the standby plant running. As already stated, this was accomplished within an hour and a half, and the pumps for the Borough Water Supply were started up again. 


\subsection{Water Supply}

The services reservoir is in the Havelock Hills, but the main from it was ruptured when the bridge at Havelock North collapsed. For several days therefore the town relied solely on the [artesian] pumps, but they did not fail them. All valves on the mains except those in the damaged area were closed, and gave barely sufficient pressure for fire fighting.

Leakage was excessive, partly on the mains themselves, but mostly due to broken service pipes to the damaged buildings. For instance, several buildings that were wrecked had 2 inch leads into them for fire protection purposes. These and smaller connections were discharging freely, and the toby box covered with debris.

The plumbers were then organised into gangs, and set about locating leaks, plugging service connections, and opening up for and closing stopcocks where possible. Still the pressure was not sufficient to float the balls in these hydrant valves, and men had to be sent to "tickle" these, in order to get them to close properly.

Stage by stage and street by street, leaks were stopped and mains put into commission again. The water was on all over the Borough by the end of the week.

Temporary repairs were made to the main where it crossed the River at Havelock, but it was not until a week or two later that the service reservoir on the hills was full and supplies assured in case of a fire.

\subsection{Fire Brigade}

The Fire Brigade Station was among the buildings damaged, but the machines were extricated and did good work in subduing the fires during the early stages of the disaster. It is thanks to their efforts that Hastings escaped so lightly from serious damage by fire.

Fire did do a considerable amount of damage, however, when the evening shake at 9 p.m. severely damaged the walls of the Power House and the plant had to be shut down until timber bracing was obtained and the walls secured safely. This was completed by 2.30 p.m. on Wednesday, and the pumps were thereafter kept running till the reservoir was full. The third big shake on Friday $13^{\text {th }}$ at 1.30 p.m. further shook the power house, crushing the ends of the timber cross bracing, necessitating further shoring, but the Engineers kept their diesels running through it all and the pumps were not stopped.

Arrangements were made to house the fire engines in a garage round the corner from the old station, and they are still there. The fire alarm circuits are still broken, and with the limited number of telephones working, the danger of serious fires is still present due to the delay in giving an alarm. Luckily few fires have occurred. The complete gutting of one house did occur, synchronising by a coincidence with the switching on of electric power in that district, but as the house was not then connected up, the fire was not due to electrical causes.

\subsection{Sewers}

The sewerage system appears to have escaped very lightly, and only minor troubles were experienced in the way of damage. There are two electrical centrifugal pumping stations, and a shone ejector system. These were supplied with power in due course, but there was too much urgency, as the sewers came back into operation only as and when the water supply was restored.

It was soon discovered that a surprisingly large number of closet pans were broken, and the Building Inspector was authorised to commander all closet pans or material for sanitary purposes in the Borough. The Council instructed all householders, per medium of the newspapers, that they must notify all cases of damage, and a staff of plumbers and drain layers was organised for prompt and systematic repairs. One plumber alone sent away for 150 closet pans.

\subsection{Electric Power}

As soon as it was found that the generators at the Power Station were functioning, many demands were made for urgent connections, and extra skilled labour was at once engaged to assist the regular linesmen in erecting poles and running services.

A B-class Broadcasting Station was in the same block as the Power Station, and wires were run over the top of wrecked buildings direct to it. But the proprietor could not get it into operation, and a valuable opportunity of sending out authentic information of the disaster, and also informing outside organisations of immediate and urgent requirements as to supplies, was lost.

Lighting was required at Relief Stores, Camping Place and Hospital. The Hospital also required electricity for the X-ray plants.

Flood lights for the devastated area were alight the first night, for protection, and street lights over the whole Borough were on by the end of the week

\subsection{Official Power}

The principle which guided the Citizens' Committee in the granting of power, was that none but official places be given a connection, and the Electrical Engineer acted only on instructions in writing from the Committee. Before any premises were declared official, the proprietor had to agree that his services and labour would be free, and that he was to do only official work, that is, he had to receive an order from the Citizens' Committee before he could do any work for any private individual or firm. All applications for electric light and power had to go before a Special Committee, which met every morning at 10 o'clock.

The Hospital required washing done, and a laundry which was intact was declared official and given power to do washing for the Hospital only.

The official transport was a very big item, and a large garage that had more or less survived the earthquake was given power for its workshop, to do repair work to official cars and trucks only. Batteries required charging, so an official 
battery charging station was organised in the yard behind the Power House with equipment from a local electrical firm.

Dangerous walls and buildings required shores and struts to be prepared, so the most suitable sawmilling and joinery works was given power. The timber was requisitioned from any timber yard available, but the machining and sawing was done at the official mill.

The Citizens' Committee required forms, tabs, instruction sheets, and other printing work run off, so an official printing press was given the electric power for its machinery.

Other essential services were given power as required, such as for bread making machinery and for cool stores as soon as these were ready to operate, but no private individual was given light or power for the first two weeks.

As soon as businesses were ready to start on a more or less normal footing and the emergency was passing, then the "official" status was cancelled, and the wiring up of business premises, temporary or otherwise, was then done in the ordinary routine way.

\subsection{Power Lines}

Cables and wires came down with the earthquake, and many poles had to be replaced. A good stock of poles was on hand at the time, and the opportunity was taken to renew any doubtful poles in the main street while free from the obstruction of verandahs. (In passing, it may be mentioned that the [Hastings Borough] Council is considering a bylaw to prevent a verandah projecting beyond a line 1' 6 " [0.45 m] in from the kerb on the main streets).

Beyond the lines to essential places, which were run as speedily as possible, wiring was done permanently, and in order to do this, the demolition of some dangerous buildings affecting the electric mains was decided on, although authority to do so was questionable.

The Borough Council's protection of service lines to houses, etc., is by means of fuses on the poles, and of linesmen supplemented by recruited skilled labour, systematically went round the streets, drew the fuses, and hung them with yarn from the crossarms. The lines were then inspected and the power progressively restored throughout the borough. The order in which the various blocks were livened up was decided by drawing the names from a hat. The work was started on $12^{\text {th }}$ February and all occupied houses had the light on by $21^{\text {st }}$ February - provided the house wiring passed inspection. Special arrangements were made to expedite the inspection of house wiring, although it was not till-after the house lighting was available and the worst earth tremors were over that the larger number of households started living indoors. There are 3,000 electrical consumers. I have not the figures for February for business premises, but during March 106 were connected, mostly temporary buildings.

\subsection{Public Health}

The Director General of health visited Hastings on Thursday, $5^{\text {th }}$ February, and the Health Department instructed a pamphlet to be issued that there was a danger of contamination of the artesian water from the sewer, that all water must be boiled, and that the sewers were not to be used.
The Borough Engineer reported that day to the Executive Committee that he had not been consulted, and that the sewers were working satisfactorily.

The fear of contamination of the artesian supplies was largely influenced by traces of petrol which were found. The supposition is that from damaged underground petrol tanks, petrol was [seeping] into the sewers, and that an interconnection was made between sewer and water mains due to fractures. The Borough Electrical Engineer reported that fuel oil had found its way into the sewers, spilling over during the 'quake.

A medical officer of health arrived to take control of the Borough on Friday, and suggested that chloride of lime be used with the water as a precautionary preventative measure. Later a chlorinating plant was installed in the Power House, and operated by a responsible officer of the Health Department.

It seems advisable to have regular analysis made of the water supply in order that a comparison may be made of conditions before and after. The presence of organic matter and other impurities may be a normal condition of the supply, or may be due to contamination due to the upheaval.

20,000 pamphlets on sanitation matters were prepared for distribution by the health officers, and articles in the public press notified the citizens of what was being done, and what they themselves were expected to do.

\subsection{The Press}

Mention must of necessity be made of the valuable work done by the press in issuing news sheets, which were essential for keeping the populace correctly informed. The single sheet bulletins were eagerly looked for, and did much to allay panic, refute alarmist and false rumours, gave publicity to all instructions of the Executive Committee regarding food supplies, medical, health, and other matters, and cheered up everyone by letting them know what assistance was coming and how the relief funds were being so freely subscribed to. It may be of interest to record the numbers of [copies of the] bulletins issued each day from the one hand plant in Hastings [as follows:] February $4^{\text {th }}-458$, $5^{\text {th }}-600,6^{\text {th }}-650,7^{\text {th }}-720,8^{\text {th }}-800,9^{\text {th }}-900,10^{\text {th }}$ $1040,11^{\text {th }}-1200,12^{\text {th }}-1500,13^{\text {th }}-1700$.

The last issue of the Earthquake Edition was on Saturday 14 February (No. 11) and the normal 4 page papers were delivered to all subscribers and agents as usual from Monday $16^{\text {th }}$ February.

\subsection{Clearing of Streets, etc}

Gangs of men totalling 400 were employed digging out the dead and clearing away debris. Foremen carpenters and builders, men used to construction and the handling of shores and scaffolding, were put in charge of the gangs, and their practical knowledge was a big aid in making walls and buildings safe for workmen to enter. Risks must be taken at a time like that, but experienced men could judge if a structure were reasonably safe for rescue operations. Sailors from the warship in Napier arrived on Thursday $\left[5^{\text {th }}\right]$ to assist in the work. Tractors and traction engines were requisitioned to help in the demolition of dangerous buildings and the removal of large masses of masonry, concrete and other 
heavy debris for the first week, but had then to be released for [wheat] threshing. Extra labour from the country districts were also released then for farm work if they so desired. It was decided by the Committee to advise outside districts by means of the Press Association that, owing to so many men being thrown out of normal employment, more than ample labour was offering within the Borough.

The demolition of dangerous buildings was a difficult manner, as legal powers for such an emergency were obscure, and questions as affecting the attitude of insurance companies immediately arose. Some owners agreed readily enough to demolition, and the Public Works Engineers were a big help in arriving at decisions, but if there was any demur from the owner, the Municipal Corporation Act proved to be too slow, probably taking some months to enforce an order. Luckily the Police have fairly wide powers, and used them judiciously to secure the safety of citizens when urgent measures were required.

The Executive Committee decided to organise carpenters and plumbers to cover up all chimney openings particularly of vacated dwellings of people who had been evacuated, in case of rain coming, and this work was started on $8^{\text {th }}$ February. Two Councillors were given authority to buy the necessary iron and stores required. On the $12^{\text {th }}$ a start was made rebuilding chimneys, but permits were granted for kitchen chimneys only, until the demand slackened. Three competent bricklayers were appointed inspectors, and their certificate was taken as a sufficient authority for this work to be done by the Public Works Department.

\subsection{Transport}

The organisation of cars and lorries was entrusted to a special committee, which apportioned the available vehicles to the various other committees according to their needs.

The transport officer also had charge of evacuations, and arranged with the Automobile Association for their cars which were organised in fleets for this purpose. Mostly women and children went away, and records were kept as much as possible of names and destination. Eight days after the 'quake 1,521 people had left by train, of whom 1,156 were refugees for whom free rail tickets to all parts of the Dominion were issued.

The transport officer also had charge of the registration of all residents of the Borough, of which more anon.

The Wellington Automobile Association was early asked to advise all other Associations that visitors would be kept out of the earthquake area, but after the $8^{\text {th }}$ February, were permitted provided they arranged their own food and accommodation.

The Railways managed to get trains running by the $4^{\text {th }}$ February, and on the $7^{\text {th }}$, the General Manager reported that he had sufficient engine power and rolling stock in the district to handle the traffic offering. Nevertheless, it was desired that only those persons engaged on urgent business requiring strictly personal attention should travel.

By the $7^{\text {th }}$ also, transport in the matter of cars was well organised, and the transport officer announced that there were 100 motor cars available above immediate requirements.
By the $12^{\text {th }}$ telegraph communication was back to normal, and the fleet of aeroplanes that did such yeoman service in providing communications and bringing up urgent supplies, were released to return to their own aerodromes.

The Railway Department also assisted in organising hospital trains for the evacuation, under full medical care, of the sick and wounded to Palmerston North and Wellington.

\subsection{FOOD SUPPLIES}

\subsection{Food Controller}

This problem was one of the most urgent and serious to be taken in hand, but I have purposely refrained from mentioning it earlier in this report, because of its wide character, and because control started at the first, and was not relinquished until the Borough was as near as could be back to a normal business footing.

The Food Controller was a one-man Committee, and wielded autocratic power, but yet in association with the Executive Committee, which put into force most of his recommendations. The guiding policy was to grant relief and adequate food supplies to all, but to so control the situation that ordinary business transactions would be developed and be put into operation as soon as general trade was practicable. There is nothing so destructive of a man's character as to make him subsist on a dole or charitable aid if there are other alternatives.

The Food Controller took charge at 2.30 p.m. on Tuesday, the day of the earthquake, and he immediately selected the King's Theatre, a large wooden building near the centre of the town, as his headquarters, and made it the principal Relief Depot.

\subsection{Food Controller's Staff}

He then appointed his staff, men chosen by himself from among the heads of warehouses and large business, and as such capable of good organisation.

Each man had his own particular line of supplies to look after and be responsible for. One looked after the meat supplies, another butter and milk. The man in charge of the bread, for instance, did nothing but organise supplies of bread. He investigated what stock he could get in the borough; saw what bakehouses, if any, had escaped the catastrophe; enquired how soon bakers would be able to start baking again and how much bread they could then make; got into communication with outside centres to find out how soon and how much bread they could deliver to him; then noted all the information down, put it before the Food Controller, and the situation was summed up. The Food Controller received these progress reports 2, 3, 4 or more times a day, knew what supplies were on hand, on the way, or could be obtained if necessary, and could act as necessity arose.

Thus he was able to report to the Executive Committee at 9 am on Wednesday, the day after the "quake that all necessary arrangements had been made for bread from Dannevirke, Waipawa, Waipukurau, etc., and for further supplies from Palmerston North later on. All local bakehouses were badly damaged. 
Each other line of food supplies was similarly handled by the one man who was responsible for it. Potatoes, sugar, tea, and other items received the same careful treatment. The local dairy factory luckily had a good stock of butter in store. Nathan's and Picot's were standing, and had supplies of sausages, savaloys, hams, and bacon.

\subsection{Control of Distribution}

Immediate instructions were given that nobody was to be supplied with goods from any private shop without an order from the Food Controller. The main idea was to stop profiteering and to see that everybody got a fair deal. Nobody starved. By assuming full control over all stocks and supplies, the Controller was able to distribute available provisions as equitably and as fairly as possible.

A Central Relief Depot was established at the Drill Hall on Wednesday morning and a staff organised for the distribution of blankets, tents, and marquees which were being rushed up to the stricken towns. There, also, the Food Controller established a branch depot as a further convenience to the populace.

The Red Cross were early on the scene and established themselves in one of the wooden schools, and freely distributed their supplies to the needy town folk.

\subsection{Petrol}

As only three bowser stations were available after the earthquake, they were immediately commandeered for essential transport, and supplies issued only on permit from the controlling authorities. This was particularly necessary in view of the many curious and sightseeing tourists who rushed up in their cars, without adequate supplies, and then wanted petrol to take them back again. However, within two days, bulk supplies were rushed up, and all restrictions on sale were removed.

\subsection{Free Stores}

Exploitation in some degree nearly always follows an emergency, and even so in the midst of this calamity, it was found that a few were prepared to take all they could get and ask for more. On the second day, therefore, the Food Controller decided to make only one depot available for free food supplies, to stop the particular few from "going the rounds". And if you stop to think a moment, there was no necessity for everyone to receive free stores. Quite a number of people as for example, members of the Public Service, Municipal employees, and others whose wages and incomes were not affected by the earthquake, were in a position to pay for their requirements. The Cabinet Ministers who visited Hastings on the Thursday also authorised the payment of all men engaged in the recovering of the dead.

The banks, however, had all closed down, and hardly anybody had any ready money. It was a fortnight before the banks opened again to put money into circulation, and the Citizens' Committee had to devise ways of meeting the situation, and yet get back to a normal footing as soon as possible. The Food Controller reported on Friday morning that food supplies were becoming somewhat more serious as people were applying for food who had no money, and on his recommendation, it was decided that all food supplies available in Hastings be commandeered and distributed by a
Committee to the people. Voluntary workers on behalf of the town were to get free food rations in return for their labour, and the sick and destitute could get certificates for free supplies from the Welfare Officer, whose staff was enlarged to meet the situation. No entry was to be made against these, but for the registered workers and those in receipt of income, credit accounts were opened at the main Food Depot, and supplies were signed for. Private firms were required to give certificates for food to employees, if required.

\subsection{Scale of Supplies, Forms, etc.}

The scale of wages for supplies was as follows:-

\section{A. Voluntary Workers}

Single men, rations up to $3 /-$ a day, [ 3 shillings $=$ $\$ 11$ in 1999 values].

Married men, rations up to $4 /$ - a day, with $1 / 6 \mathrm{~d}$ extra for each child up to a maximum of $8 / 6 \mathrm{~d}$ a day.

B. Those not employed, etc.

A similar but reduced scale up to a maximum of $6 / 6 d$ a day.

[Identification certificates and ration cards were issued to voluntary workers.]

A restaurant was established, and those not wanting rations, as, for example, single men, or men whose families were away, could get a meal for $1 /$ [ [ $\$ 3.50$ in 1999 values] or a snip of the ration card.

As each workman entered the Food Depot, he went up to one of the six clerks who had pads and price lists in front of them. The workman enumerated the goods he required, and the clerks noted them down, priced them, and then adjusted the items or the quantities to keep within the limits of the allowance.

The lists were then submitted to the counter assistants who proceeded to supply the goods required. By this means the provisions for 10,000 people were quickly handled and with a minimum of inconvenience and dispute.

For those without ready cash, but otherwise in a position to pay for supplies, forms were issued for recording credit charges.

\subsection{Commandeered and Salvaged Stocks}

I have already mentioned that all private trading was stopped, and that the Food Controller, immediately after the earthquake, took over all supplies. Lorries were sent round to grocers and provision merchants, and their stocks were as far as possible salvaged and commandeered for the Relief Depots. You will realise that no one was normal, that the continual tremors were upsetting to even strong intellects, and in consequence many mistakes were made. And one that the Food Controller admits making in those earlier days - and one cannot blame him - is that he did not sit down and think out just what goods he particularly required to salvage. You see, he cleaned up all salvageable stock he could get, without arranging for checking it over or getting authority, and so when later on, claims started to come in from the storekeepers and merchants, he found himself in an invidious position, he could not check the claims. Further, he found that he had large quantities of stores for which he had no 
demand whatever, and which occupied a lot of valuable space in his depot.

One large establishment for instance put in a claim for $£ 11,000$ worth of stores $[\$ 770,000$ in 1999 values]. Investigation provided that the Food Controller had $£ 4,600$ worth of this firm's goods which were of no value to him, and which he promptly returned. Of the balance, all except $£ 1,000$ worth was accounted for. As three walls of the store had collapsed, it had to be assumed that $£ 1,000$ was the value of goods stolen or destroyed. Similarly in other instances, firms had copies of their stock sheets as a guide, but the most exacting enquiries had to be made as to why the goods were commandeered, by whom, and whose authority, before the question of payment could be decided.

It is essential in all similar cases that proper records be kept of everything done. It may take more time to get going and will require a larger staff, but it is the only satisfactory footing on which to work. The second important point is to salvage only what is required. If sugar is wanted, hunt around and take what sugar supplies can be salvaged but leave all other goods alone. If they are not wanted, they will still remain of salvage value to the owner of the shop. It is desirable to get the owner to check and countersign the requisition for commandeering, but if he cannot be found, then at least keep a careful record of what is being done.

Similarly supplies of meat and foodstuffs were coming to hand by rail as soon as this service was re-established, and the Relief Depots took it on consignment, just paying for what was used.

\subsection{Local Supplies}

Supplies of bread and meat, etc., were rushed up from outside sources, and were the means, the only means, of enabling the population of the stricken area to stay on. But it was also necessary that local sources of supplies be re-established as soon as possible. Luckily nearly all the milkmen in Hastings carried on with as far as possible their usual rounds even the day after the disaster.

Bakehouses were temporarily re-established, and in order to keep the meat wholesome, the Food Controller called on the plumbers to make him large trays to fit the bakers' ovens, and on withdrawal of the batches of bread, sheep and joints of beef were put in and were roasted beautifully. Early birds had the meat hot, but to most of the people it was distributed cold.

A killing gang was tentatively arranged for, to proceed to various farms and kill and dress the sheep, at an estimated cost of I think 5/6 a carcass, as the freezing works were asking $2 \mathrm{~d}$ per $\mathrm{lb}$. However, these gangs were very quickly, and supplied mutton at $1 \frac{1}{8} \mathrm{~d}$ per $16 \mathrm{lb}$. on the hooks, and beef for $12 / 6 \mathrm{~d}$ per $100 \mathrm{lb}$.

Thus every endeavour was made to get adequate supplies to hand, at the cheapest possible rate, and to establish all transactions on a financial basis. If anyone was in a doubtful financial position, he was at least charged with the goods, and his circumstances could later be investigated by the Relief Committee which would if necessary pay the accounts for him.

\subsection{The Red Cross}

On Saturday, the Mayor, the Food Controller, and the representative of the Red Cross had a conference, when the question of the indiscriminate granting of free supplies was raised, it being the opinion of the Red Cross Society that supplies should be absolutely free and no charge made to anyone. Their notices displayed "Food galore, clothes galore, ask for everything you want" - and they had to borrow from the Food Controller sometimes to meet the demand. The Red Cross Society, however, began to realise the position, and in appreciation of the aims of the Citizens' Committee, it was announced on Sunday morning that free meals could not be continued at the Red Cross Depot, but that the Food Controller would supply requirements in the meantime.

\subsection{Registration}

On Monday, February $9^{\text {th }}$, a further step towards more normal business was taken by deciding that volunteer work be eliminated as soon as a workers' register could be compiled, and that actual payment of wages be made, sufficient to produce food for the worker on a scale according to the number of dependents. Payment for this would have to be recovered from the National Unemployment Fund or a special grant from the Government. There were 500 men in Hastings with no work and no money, and the fear was lest outsiders [move] in, looking for employment or imposing on the disorganised situation due to the disaster. The services of the Transport officer were therefore sought, and with the aid of his staff, a complete register of all workers was made out, with a list of their dependents. As the basis of the register, the Transport officer made use of the Municipal Roll, and his number on the roll was shown on his card in the file.

Men applying for registration in order to get work, and not on the Municipal Roll, were required to prove that they were bona-fide residents of the Borough before their names were accepted.

The experience of Hastings was that there were more men available than could be usefully employed, and it was essential that local men should have first preference of all work offering. Business was at first absolutely dislocated, and even with temporary shops in commission, a proportion of the sales and office staff, etc., of the various firms could not be absorbed into their old occupations.

Registration ensured that local men were given the preference, and kept relief services down to suit purely local needs.

\subsection{Outlying Settlers}

Farmers and settlers living outside the Borough limits were naturally included in the relief work, and had to come to the Depots for supplies. But once the Food Controller had his organisation functioning and had arranged for equitable distribution of supplies to everyone, he then ordered the formation of sub-committees in each area of settlement in the country districts, and only one man from that sub-committee could procure supplies for the rest of his neighbours. The sub-committee had to receive all requests for the stores, procure them, and then see to their distribution, and where people were unable to pay cash, the goods were charged against them and they had to sign for them. 
After the first week, the local storekeeper was appointed as a sub-agent of the Food Controller, and supplies were given him for distribution. But no goods were given where the settler could pay, and therefore all goods were entered on charge sheets if not paid for by cash. Everyone was supplied with necessities, which of course is the most important point, no one was allowed to starve, but yet records were kept of all supplies given, so that those who should pay could be asked to, and the goods supplied to those not in a position to pay were charged up later to the Relief Funds.

\subsection{Rebuilding of Shops and Business Premises}

Naturally, the destruction caused by the earthquakes made responsible people enquire as to what could be considered earthquake proof construction for permanent buildings, and in the earthquake areas of Napier and Hastings it was promptly decided that no structure other than in wood, corrugated iron, or similar material would be allowed until the gazetting of the Government Regulations.

Shopkeepers and business men were urged, however, to resume as early as possible, and when by the beginning of the second week, streets and sections in the devastated area were fast being cleaned up, permits were granted for temporary premises. These permits allowed a building to be erected and to remain for two years only. As long as the structure was weatherproof and decently constructed, it mattered not how rough it looked. Some Councillors maintained that the rougher the better, as there would then be no desire to extend the permit beyond the two years.

I understand that the Government advanced the money for temporary premises, to be repaid at 25/- weekly over a period of two years by way of rent and without interest.

Tradesmen and businessmen readily availed themselves of the opportunity, and nearly all essential stores were open with full trading facilities by the $15^{\text {th }}$ of February.

\subsection{RESULTS OF WORK OF CITIZENS COMMITTEE}

It must be realised that in Hastings the Citizens' Executive Committee functioned for a fortnight only, but the work it did in that first fortnight was a most inspiring record of teamwork and organisation on behalf of a stricken town.

The Mayor was absent on the morning of the big 'quake, and then his Deputy was called upon to take charge of the Fire fighting services of which he was superintendent. Yet the leading citizens rallied together, and formed a committee which immediately took charge of the whole situation. The Mayor on his return on Thursday afternoon after an arduous trip through Taupo (an aeroplane was sent to Wairoa for him, but just missed his car there), was promptly asked to take the chair of the Committee, and every member gave him their loyal support.

The Council met on the evening of the $3^{\text {rd }}$ February and whenever necessary thereafter, to transact internal borough authority for urgent work.

Councillors and members of the Earthquake Executive worked and collaborated together for the sake of the community in all the various activities, realising that the strongest men were required at the head of each department of organisation. The Citizens' Committee met every morning at 9 a.m., when all reports were received, deputations met, and consultations held with Ministers of State, Members of Parliament, and Mayors and Councillors of sister Boroughs and Cities of the Dominion. A special member of the Executive was appointed to assist the Mayor and Town Clerk in replying to correspondence, telegrams, and the numerous offers of assistance and help.

Daily conferences were the keynote of co-operation, and even the sub-committees met every morning. The Food Controller for instance met the heads of all his departments at 7.30 every morning. Yet these conferences and committees were but the showing of a united front in the face of a dire calamity. The real work was done by each man in charge of his own particular sphere of action taking full control and doing just what he considered necessary without fear or favour. Democracy was forgotten, and autocracy held sway.

But only for about a fortnight. So much progress had then been made that business was well on the way to normal, but the real reason was that the Committee found itself so hampered in every way by lack of authority and by such a lack of much needed Government support, that it had to hand over relief work, expenditure, food and all other services to the Borough Council, and assume an advisory capacity only.

Finance and authority, two big worries in any such emergency, and were anything of the kind to occur tomorrow anywhere in this Dominion, we are little better prepared, we have no legislation yet, [24 April 1931.]

Financial matters, the payment of labour, the charging for stores, the endeavour to set business on its cash trading basis as soon as possible, the failure of all banks except the Post Office Savings Bank to function until a fortnight had elapsed, have been touched on in these few notes. But I am not a financial expert, and I trust some one abler than I will investigate the position from a truly financial aspect and give us the benefit of his observations.

Lastly there is the most difficult of all problems, a problem which is far from being solved as yet, the adjustment of claims for relief; and assistance in repairing and restoring damaged property and ruined businesses. This paper deals with the first phase of the re-organisation after an upheaval of Nature. I leave the second phase, the phase only just being entered upon really, the rehabilitation of a devastated and stricken area.

\section{ACKNOWLEDGEMENTS}

David Dowrick is grateful to Chris Johnson, the Hastings District Council Archivist, for alerting him to the existence of Edwin Scott's report. The report was discovered amongst the letters and papers after his death by his engineer son, Bruce, who sent it to the Hastings District Council (in 1997) and who also supplied the biographical notes which I have given in the Summary and Preface. 


\section{REFERENCES}

Readers of the above report wishing to gain more information on the damage context applying to the above report may start with the recent paper cited below, which gives data on damage to buildings and lifelines in Hastings (among other places) as well as further source references.

1. Dowrick, D. J. (1998) Damage and intensities in the magnitude 7.81931 Hawke's Bay, New Zealand, earthquake, Bulletin New Zealand National Society for Earthquake Engineering, 30(2), 133-158. 